\title{
Recurrent Venous Thrombosis: Is there a Place for Methylenetetrahydrofolate Reductase Polymorphisms?
}

\author{
Sónia Moreira*, Mariana Gonçalves, Elsa Gaspar and Lèlita Santos \\ Department of Internal Medicine, Centro Hospitalar e Universitário de Coimbra, Portugal \\ Submission: May 25, 2018; Published: May 31, 2018
}

*Corresponding author: Sónia Moreira, Department of Internal Medicine, Centro Hospitalar e Universitário de Coimbra, Praceta Prof. Mota Pinto, 3000-075 Coimbra, Portugal, Tel: 00351 239400400; Email: soniabastosmoreira@gmail.com

\begin{abstract}
Inherited and acquired prothrombotic states play an important role in the development of venous thrombosis. We present a case of a 31year old Caucasian woman with cerebral venous thrombosis followed by superior vena cava thrombosis. The patient had a previous distal deep vein thrombosis event. Regarding the extent of thrombosis and young age, she underwent screening for genetic thrombophilia. A composed heterozygosity was identified for Methylenetetrahydrofolate Reductase (MTHFR C677T/A1298C) with elevated homocysteine levels. In this report we discuss the evaluation and management of thrombosis in young patients and the association between stroke and mutation of the methylene tetrahydrofolate reductase gene.
\end{abstract}

Keywords: Venous Thrombosis; Methylenetetrahydrofolate Reductase; Homocysteine,Genetic thrombophilia

\section{Introduction}

Venous thrombosis (VT) is a multifactorial disease due to the interplay of acquired and inherited prothrombotic causes and environmental factors [1]. Several genetic thrombophilic conditions have been identified, including polymorphisms of the methylene tetrahydrofolate reductase (MTHFR) [2]. MTHFR reduces methylene tetrahydrofolate to 5-methyl tetrahydrofolate and transfers a methyl group to homocysteine, forming methionine. When present in homozygothy, the two common polymorphisms, C677T and A1298C, have been associated with decreased enzyme activity resulting in hyperhomocysteinemia (HCY) [3]. HCY is a well-known risk factor for vascular diseases, including ischemic heart disease, cervical arterial dissection, stroke and venous thrombosis in healthy population [4]. Routine screening for inherited hypercoagulable disorders is not indicated for all patients with VT but should be performed in selected cases [5,6]. We report a case of a young woman with massive recurrent $\mathrm{VT}$ with recognized composed heterozygosity in MTHFR gene.

\section{Case Report}

A 31-year-old Caucasian woman was admitted to the emergency room with severe and constant headache for 2 days. No relief was achieved after treatment with several analgesic therapies. She had no complaints of nausea or vomiting and denied ocular and focal neurological symptoms. Her past medical history revealed a previous episode of distal deep vein thrombosis three years earlier. Episodes of superficial thrombophlebitis, distal ischemia, raynaud phenomenon, recent surgery or immobilization were not registered. Our patient was a low-pack smoker (4 packs-years) and used oral hormonal contraception. Family history was negative for cerebrovascular diseases and cancer. Physical examination revealed terminal neck stiffness and funduscopic examination was suggestive of bilateral macular edema. No focal sensory-motor signs were present.

Brain computed tomographic (CT) venography revealed venous thrombosis of the superior sagittal sinus, extending to the left sigmoid sinus and right transverse sinus (Figure 1). Electrocardiogram, echocardiogram and chest x-ray were normal, as well as the remaining routine laboratory tests, including differential blood cell count, prothrombin, partial thromboplastin times, serum glucose, creatinine, electrolytes, liver enzymes, and calcium. Screening for occult cancer was negative.

Since the patient was young $(<45$ years), athrombophilia panel was obtained. Protein C, protein S, antithrombin III, antiphospholipid antibodies and lupus anticoagulant and 


\section{Juniper Online Journal of Case Studies}

resistance to activated protein $\mathrm{C}$ were in the normal range. Mutation analysis of the prothrombin gene and factor $\mathrm{V}$ Leiden was unremarkable. After these results this panel was extended and 4 heterozygous gene mutations were identified, including MTHFR C677T and A1298C, glycoprotein GP3A and Fibrinogen- $\beta$ G/A-455. Total homocysteine was $16 \mu \mathrm{mol} / \mathrm{L}$ (normal value < $12 \mu \mathrm{mol} / \mathrm{L})$. The levels of folic acid and cobalamine were within normal range.
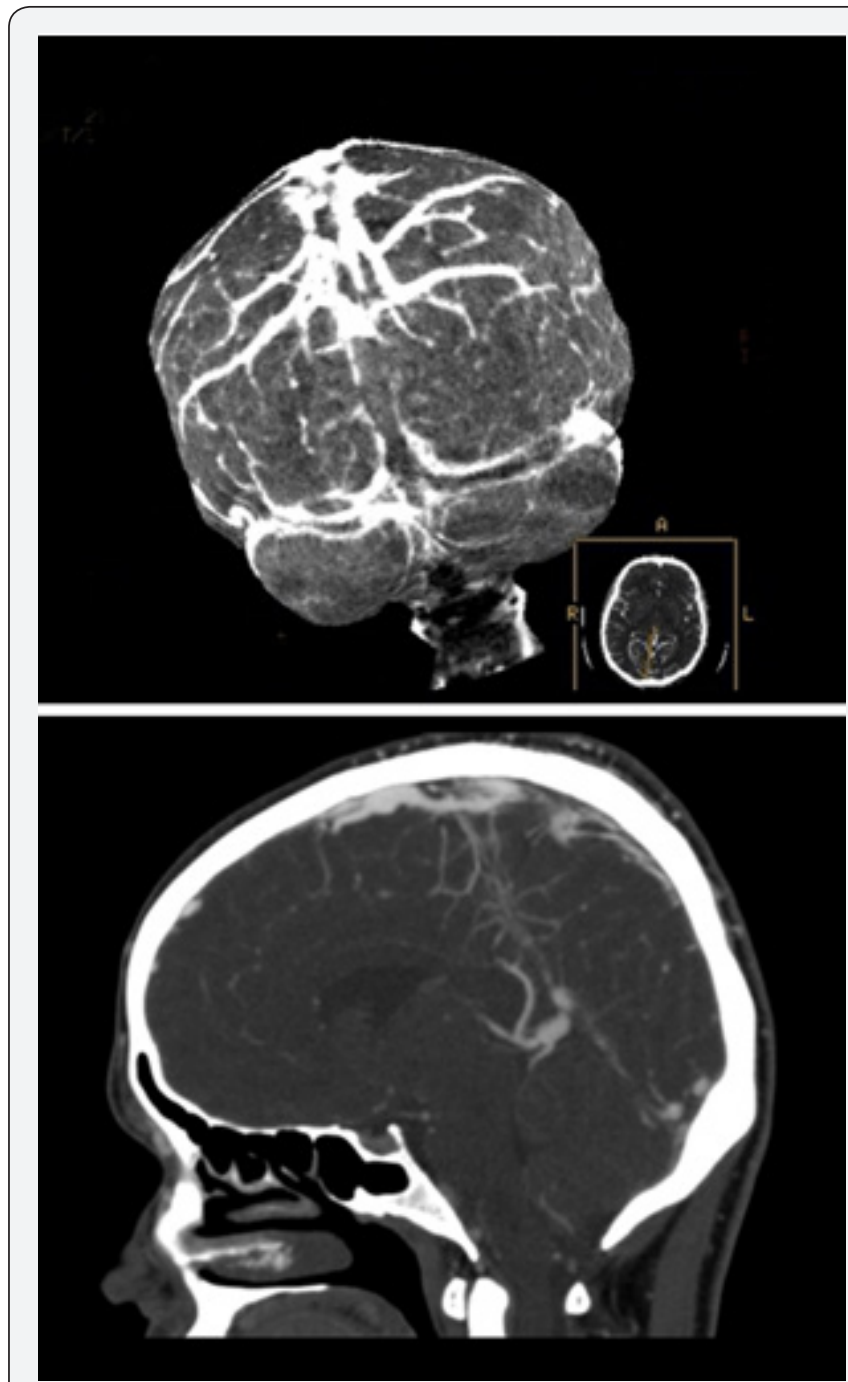

Figure 1: Brain computed tomographic venography showing thrombosed superior sagittal, transverse and sigmoid sinuses.

She was treated with dexamethasone $5 \mathrm{mg}$ twice daily and low molecular weight heparin (enoxaparin $60 \mathrm{mg}$ twice daily). Hormonal contraception was withdrawn and she quitted smoking. Clinical improvement was observed and she was discharged on oral anticoagulation with warfarin. Twomonth later the patient was readmitted due to facial edema, venous engorgement and extensive collateral circulation (Figure 2). The CT angiography revealed superior vena cava thrombosis and signs of extensive cervical, thoracic and abdominal collateral circulation (Figure 3). International normalized ratio (INR) was 2.49 (adequate range 2-3). She was treated with LMWH (60mg enoxaparin twice/day) and later discharged with acenocoumarol. No recurrence of thrombosis was found during the next 10 years of follow-up.

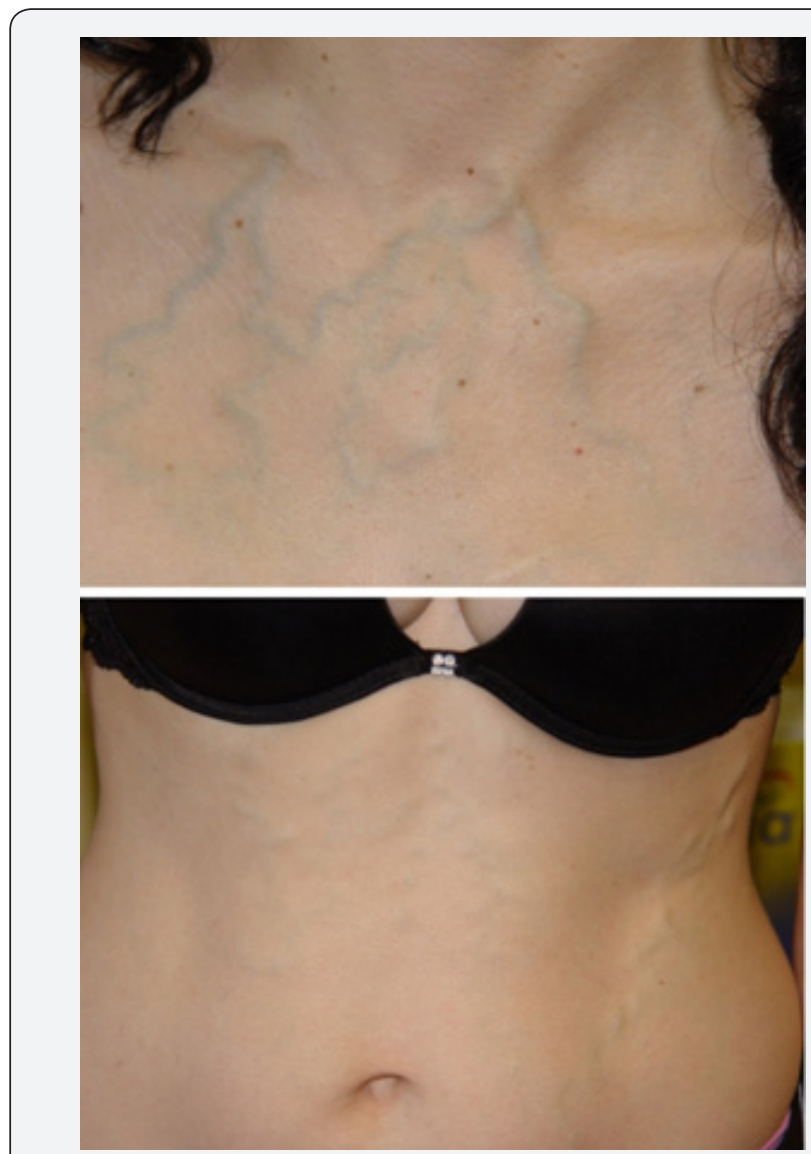

Figure 2: Venous engorgement with extensive superficial collateral circulation at thorax and abdomen.

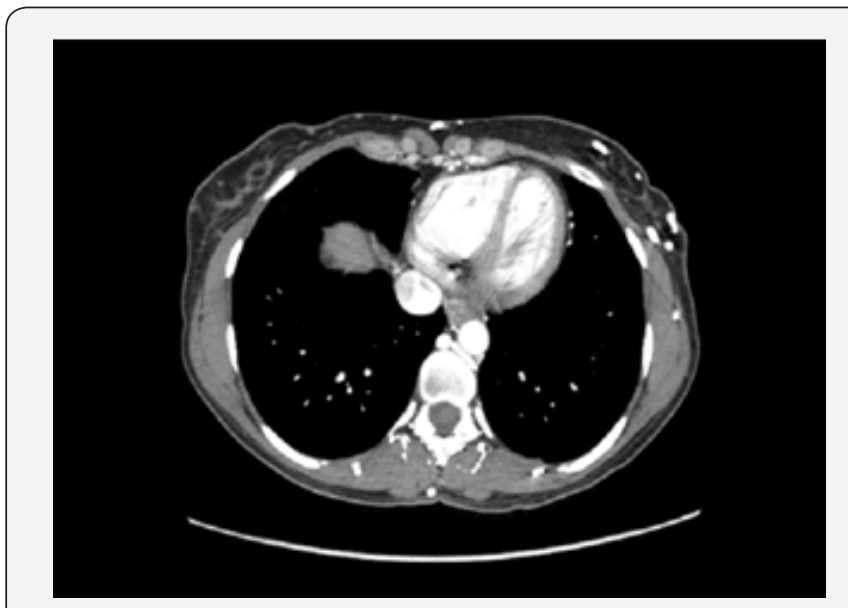

Figure 3: Thoracic contrast-enhanced computed tomography showing signs of extensive collateral circulation as well as superior vena cava thrombosis.

\section{Discussion}

In our case report, a young woman with combined heterozygous polymorphisms in MTHFR (C677T and A1298C) 
presented with recurrent venous thrombosis involving different vascular beds. Isolated heterozygous mutations in MTHFR have not been associated with increased risk of thrombotic events. However, Spiroski et al. [7] found a statistically significant increase in homocysteine for the combined heterozygote haplotype [7]. An epidemiological study indicated that the combined effect of these two polymorphisms may be synergic mainly in the trans positions (mutation occurring in different alleles), therefore a combined polymorphisms and haplotype analysis may result in a more effective approach than a single polymorphism approach [8-10]. We did not investigate whether our patient presented MTHFR mutation in the cis or trans conformation, nor looked for linkage analysis, but regarding that our patient had increased levels of HCY, the presence of a trans form is more likely. Two case reports of venous cerebral thrombosis occurring in pediatric age described an association with double heterozygote status in MTHFR, one with high HCY levels and the remaining with normal levels [11,12]. Also, Ringwald et al. [13] described higher frequency of deep VT after elective total hip arthroplasty in patient with combined heterozygous status of MTHFR C677T and A1298C [13].

Venous thrombosis is frequently the result between interplay of genetic and environmental factors. In a recent metaanalysis, smoking was an independent risk factor for VT in a dose-dependent way [14]. Moreover, a synergic effect on VT risk for smoking, oral contraceptive use, and genetic prothrombotic risk factors has been described [15]. Pomp et al. [15] reported an increase in Odds Ratio for VT from 3.90 for oral contraceptive users to 8.79 when current smoking was added [15]. Our patient was a low pack year-consumption smoker and was initially on oral contraceptive use, thereby we cannot exclude a possible synergic effect of smoking and oral contraceptive use with MTHFR composed heterozygosity for this extensive recurrent thrombosis.

\section{Conclusion}

In conclusion, routine evaluation for hypercoagulable disorders in unselected patients with a diagnosis of VTE is not warranted. However, testing in selected populations should be considered, namely in patients with a family history of VTE, young age $(<45$ years), recurrent thrombosis, thrombosis in multiple venous sites or in unusual vascular beds (e.g., portal, hepatic, mesenteric, or cerebral veins), and arterial thrombosis

\section{References}

1. Yokus O, Albayrak M, Balcik OS, Ceran F, Dagdas S, et al. (2009) Risk factors for thrombophilia in young adults presenting with thrombosis. Int J Hematol 90(5): 583-590.
2. Souto JC, Almasy L, Borrell M, Blanco-Vaca F, Mateo J, et al. (2000) Genetic susceptibility to thrombosis and its relationship to physiological risk factors: the GAIT study. Genetic Analysis of Idiopathic Thrombophilia.. Am J Hum Genet 67(6): 1452-1459.

3. Isotalo PA, Donnelly JG (2000) Prevalence of methylenetetrahydrofolate reductase mutations in patients with venous thrombosis. Mol Diagn 5(1): 59-66.

4. Eldibany MM, Caprini JA (2007) Hyperhomocysteinemia and thrombosis: an overview. Arch Pathol Lab Med 131(6): 872-884.

5. Baglin T, Gray E, Greaves M, Hunt BJ, Keeling D, et al. (2010) Clinical guidelines for testing for heritable thrombophilia. Br J Haematol 149(2): 209-220.

6. Nicolaides AN, Fareed J, Kakkar AK, Comerota AJ, Goldhaber SZ, et al. (2013) Prevention and treatment of venous thromboembolism-International Consensus Statement. Int Angiol 32(2): 111-260.

7. Spiroski I, Kedev S, Antov S, Arsov T, Krstevska M, et al. (2008) Methylenetetrahydrofolate reductase (MTHFR-677 and MTHFR-1298) genotypes and haplotypes and plasma homocysteine levels in patients with occlusive artery disease and deep venous thrombosis. Acta Biochim Pol 55(3): 587-594.

8. Palmirotta R, Leone B, De Marchis ML, Ludovici G, Savonarola A, et al. (2013) An importance of identification of double variant methylenetetrahydrofolate reductase gene C677T and A1298C in cis configuration for pharmacogenetic studies. Blood Coagul Fibrinolysis 24(7): 784-786.

9. Toffoli G, De Mattia E (2008)Pharmacogenetic relevance of MTHFR polymorphisms. Pharmacogenomics 9(9): 1195-1206.

10. Ulvik A, Ueland PM, Fredriksen A, Meyer K, Vollset SE, et al. (2007) Functional inference of the methylenetetrahydrofolate reductase $677 \mathrm{C}$ $>\mathrm{T}$ and 1298A > C polymorphisms from a large-scale epidemiological study. Hum Genet 121(1): 57-64.

11. Bozzola E, Bozzola M, Colafati GS, Calcaterra V, Vittucci A, et al. (2014) Multiple cerebral sinus thromboses complicating meningococcal meningitis: a pediatric case report. BMC Pediatr 14: 147.

12. Behpour-Oskooee M, Karimi A, Sayyahfar S (2014) Lemierre's syndrome with double heterozygote status in the methylenetetrahydrofolate reductase gene. World J Pediatr 10(3): 281-283.

13. Ringwald J, Berger A, Adler W, Kraus C, Pitto RP (2009) Genetic polymorphisms in venous thrombosis and pulmonary embolism after total hip arthroplasty: a pilot study. Clin Orthop Relat Res 467(6): 1507-1515.

14. Cheng YJ, Liu ZH, Yao FJ, Zeng WT, Zheng DD, et al. (2013) Current and former smoking and risk for venous thromboembolism: a systematic review and meta-analysis. PloS Med 10(9): e1001515.

15. Pomp ER, Rosendaal FR, Doggen CJ (2008) Smoking increases the risk of venous thrombosis and acts synergistically with oral contraceptive use. Am J Hematol 83(2): 97-102. 


\section{Your next submission with Juniper Publishers will reach you the below assets}

- Quality Editorial service

- Swift Peer Review

- Reprints availability

- E-prints Service

- Manuscript Podcast for convenient understanding

- Global attainment for your research

- Manuscript accessibility in different formats ( Pdf, E-pub, Full Text, Audio)

- Unceasing customer service

Track the below URL for one-step submission https://juniperpublishers.com/online-submission.php 